\title{
Tsukamurella inchonensis sp. nov.
}

\author{
A. F. YASSIN, ${ }^{1 *}$ F. A. RAINEY, ${ }^{2}$ H. BRZEZINKA, ${ }^{3}$ J. BURGHARDT, ${ }^{2}$ H. J. LEE, ${ }^{4}$ AND K. P. SCHAAL ${ }^{1}$ \\ Institut für Medizinische Mikrobiologie und Immunologie der Universität Bonn, 53127 Bonn, ${ }^{1}$ Deutsche Sammlung \\ von Mikroorganismen und Zellkulturen $\mathrm{GmbH}, 38124$ Braunschweig, ${ }^{2}$ and Institut für Rechtsmedizin \\ der Universität Bonn, 53111 Bonn, ${ }^{3}$ Germany, and Department of Clinical Pathology, \\ College of Medicine, Kyung Hee University, Seoul, South Korea ${ }^{4}$
}

\begin{abstract}
Chemotaxonomic and genomic $16 S$ ribosomal DNA sequence analyses of two isolates obtained from two different clinical materials clearly delineated a new species of the genus $T$ sukamurella. This new species can be identified by its $16 \mathrm{~S}$ ribosomal DNA similarity values, as well as its physiological characteristics. The name Tsukamurella inchonensis sp. nov. is proposed for these isolates, which are represented by strain IMMIB D-771 $\left(=\right.$ DSM $\left.44067^{\mathrm{T}}\right)(\mathrm{T}=$ type strain). This strain exhibits only $45 \%$ DNA relatedness to Tsukamurella paurometabola.
\end{abstract}

In 1941 Steinhaus (28) isolated Corynebacterium paurometabolum from mycetomas and ovaries of bed bugs (Cimex lectularius). However, assignment of this species to the genus Corynebacterium has been questioned since then by several workers $(4,5,16)$. Although $C$. paurometabolum resembles true corynebacteria in having a directly cross-linked murein based on meso-diaminopimelic acid and an arabinogalactan polymer $(8,27)$, it can be distinguished from them because it possesses an unusual series of very long (68- to 76-carbon atom), highly unsaturated (two- to six-double bond) mycolic acids (5).

A similar series of very long, highly unsaturated mycolic acids has been found in Rhodococcus aurantiacus (12, 29). However, the generic position of $R$. aurantiacus has also been questioned $(10,12)$. This species was first described by Tsukamura and Mizuno (33) in 1971 as "Gordona aurantiaca." The genus Rhodococcus (Zopf) was resurrected by Goodfellow and Alderson (11) for strains classified in the genus "Gordona" and members of the "rhodochrous" complex. In a numerical phenetic study Goodfellow et al. (12) found that "G. aurantiaca" strains formed a well-defined taxon quite distinct from the genera Mycobacterium, Nocardia, and Rhodococcus. Therefore, these authors considered " $G$. aurantiaca" worthy of generic status (12). Tsukamura $(30,32)$ and Tsukamura and Yano (35) subsequently assigned "G. aurantiaca" to the genus Rhodococcus. In addition to possessing series of highly unsaturated mycolic acids, $C$. paurometabolum and $R$. aurantiacus differ from other mycolic acid-containing taxa by producing menaquinones with unsaturated multiprenyl side chains (the major component is MK-9). Members of the genera Corynebacterium, Mycobacterium, Nocardia, and Rhodococcus invariably synthesize menaquinones with partially saturated side chains.

On the basis of the results of a 16S rRNA sequence analysis Collins et al. (7) concluded that $C$. paurometabolum and $R$. aurantiacus were highly related to each other (level of sequence homology, more than $99 \%$ ) but were distinct from the genera Corynebacterium, Mycobacterium, Nocardia, and Rhodococcus. On the basis of these and previous chemotaxonomic findings Collins et al. (7) proposed "that Corynebacterium paurometabolum and Rhodococcus aurantiacus be re-

${ }^{*}$ Corresponding author. Mailing address: Institut für Medizinische Mikrobiologie und Immunologie der Universität Bonn, SigmundFreud-Strasse 25, 53127 Bonn, Germany. duced to a single species and reclassified in a new genus, Tsukamurella," as Tsukamurella paurometabolum comb. nov. The correct form of this species designation is Tsukamurella paurometabola because the noun Tsukamurella is feminine and the corresponding adjective should also have a feminine ending.

While applying chemotaxonomic methods to the identification of bacteria that had been isolated from clinical specimens under routine diagnostic conditions, we encountered two unusual isolates. These organisms have chemotaxonomic and phylogenetic characteristics which suggest that they should be included in the genus Tsukamurella.

\section{MATERIALS AND METHODS}

Bacterial strains. Strain IMMIB D- $771^{\mathrm{T}}(\mathrm{T}=$ type strain) was isolated from four independent blood cultures of a patient who had ingested hydrochloric acid The other strain, strain IMMIB AL-1155, was isolated from a smear from the left lung of a patient who suffered from a necrotic tumor of this lung. $T$. pauro metabola DSM $20162^{\mathrm{T}}$ was obtained from the Deutsche Sammlung von Mikroorganismen und Zellkulturen $\mathrm{GmbH}$.

Characterization of strains. Colony morphology and the ability to grow at various temperatures $\left(24,31,37\right.$, and $\left.45^{\circ} \mathrm{C}\right)$ were determined after 1 week of incubation on Loewenstein-Jensen medium slants. The following properties were determined as described previously: the niacin test was performed by using tes strips (Difco Laboratories, Detroit, Mich.) $(18,37)$; nitrate reductase activity was determined by the method of Kubica and David (19); catalase activity at $68^{\circ} \mathrm{C}$ was determined by the method of Kubica and Pool (20); arylsulfatase activity after 3 days was determined by the method of Kubica and Ridgon (21); $\beta$-glucosidase and $\beta$-galactosidase activities were determined by the method of Tsukamura (31); Tween 80 hydrolysis was determined by the method of Wayne et al. (36); growth on MacConkey agar was determined by the method of Pattyn and Portaels (25); resistance to $\mathrm{NaCl}$ and $p$-nitrobenzoic acid was determined by the methods of Wayne et al. (36) and Tsukamura and Tsukamura (34); acetamidase, allantoinase, benzamidase, nicotinamidase, pyrazinamidase, succinamidase, and urease activities were determined by the method of Bönicke (2); and tests to determine resistance to streptomycin $(4.0$ and $8.0 \mu \mathrm{g})$, isoniazid $(0.25$ and 1.0 $\mu \mathrm{g}$ ), ethambutol $(8.0,16.0$, and $32.0 \mu \mathrm{g}$ ), rifampin (16.0 and $32.0 \mu \mathrm{g}$ ), $p$-aminosalycylic acid (16 and $32.0 \mu \mathrm{g})$, protionamide $(16.0$ and $32.0 \mu \mathrm{g}$ ), capreomycin $(16.0$ and $32.0 \mu \mathrm{g})$, and cycloserine $(16.0$ and $32.0 \mu \mathrm{g})$ were performed by using Loewenstein-Jensen medium slants supplemented with different concentrations of these antibiotics (Biotest). Tests to determine decomposition of adenine, guanine, hypoxanthine, xanthine, tyrosine, elastine, keratine, and testosterone were performed by the method of Gordon and Smith (15); tests to determine esculin decomposition were performed by the method of Gordon (13); and tests to determine casein and gelatin hydrolysis were performed by the method of Gordon and Mihm (14). Urea decomposition was tested by using urea agar base (code CM 53; Oxoid) after 2.2\% urea was added. To determine utilization of carbon sources we used a basal medium (which contained [per liter of distilled water] $1.5 \mathrm{~g}$ of $\mathrm{KH}_{2} \mathrm{PO}_{4}, 0.5 \mathrm{~g}$ of $\mathrm{MgSO}_{4}, 0.1 \mathrm{~g}$ of $\mathrm{CaCl}_{2}, 5.0 \mathrm{~g}$ of $\left(\mathrm{NH}_{4}\right)_{2} \mathrm{SO}_{4}$, and $0.5 \mathrm{~g}$ of $\mathrm{KNO}_{3}$ ) supplemented with a trace salt solution (which contained [per liter of distilled water] $50.0 \mathrm{mg}$ of $\mathrm{H}_{3} \mathrm{BO}_{3}, 4.0 \mathrm{mg}$ of $\mathrm{CuSO}_{4} 10.0 \mathrm{mg}$ of $\mathrm{KI}, 20.0$ $\mathrm{mg}$ of $\mathrm{FeCl}_{3}, 40.0 \mathrm{mg}$ of $\mathrm{MnSO}_{4}$, and $40.0 \mathrm{mg}$ of $\mathrm{ZnSO}_{4}$ ) and a vitamin solution (which contained [per $100 \mathrm{ml}$ of distilled water] $0.2 \mathrm{mg}$ of biotin, $10.0 \mathrm{mg}$ of 
TABLE 1. Differential physiological characteristics of strains IMMIB D- $771^{\mathrm{T}}$ and IMMIB AL-1155 and T. paurometabola DSM $20162^{\mathrm{T}}$

\begin{tabular}{|c|c|c|c|}
\hline Characteristic & $\begin{array}{l}\text { Strain } \\
\text { IMMIB } \\
\text { D-771 }^{\mathrm{T}}\end{array}$ & $\begin{array}{l}\text { Strain } \\
\text { IMMIB } \\
\text { AL-1155 }\end{array}$ & $\begin{array}{l}\text { T. paurometabola } \\
\text { DSM } 20162^{\mathrm{T}}\end{array}$ \\
\hline \multicolumn{4}{|l|}{ Hydrolysis of: } \\
\hline Adenine & $-{ }^{a}$ & - & - \\
\hline Hypoxanthine & + & + & - \\
\hline Tyrosine & - & - & - \\
\hline Xanthine & - & - & - \\
\hline Casein & - & - & - \\
\hline Urea & + & + & + \\
\hline Esculin & + & + & + \\
\hline Gelatin & - & - & - \\
\hline Elastin & - & - & - \\
\hline Guanine & - & - & - \\
\hline Keratin & - & - & - \\
\hline Testosterone & - & - & - \\
\hline Tween 80 & + & + & + \\
\hline \multicolumn{4}{|c|}{$\begin{array}{l}\text { Utilization of the following } \\
\text { compounds as sole } \\
\text { sources of carbon and } \\
\text { energy: }\end{array}$} \\
\hline Arabinose & - & - & - \\
\hline Xylose & - & - & - \\
\hline Glucose & + & + & + \\
\hline Galactose & + & + & + \\
\hline Rhamnose & - & - & - \\
\hline Lactose & - & - & - \\
\hline Maltose & + & + & - \\
\hline Raffinose & - & - & - \\
\hline Trehalose & + & + & + \\
\hline Sucrose & + & + & + \\
\hline Cellobiose & + & - & - \\
\hline Melezitose & + & + & - \\
\hline Adonitol & - & - & - \\
\hline Erythritol & - & - & - \\
\hline Inositol & + & + & - \\
\hline Mannitol & + & + & - \\
\hline D-Sorbitol & + & + & - \\
\hline Acetate & + & + & - \\
\hline Benzoate & - & - & - \\
\hline Citrate & + & + & + \\
\hline Gluconate & + & + & + \\
\hline Lactate & + & + & - \\
\hline$m$-Hydroxybenzoate & - & - & - \\
\hline p-Hydroxybenzoate & - & - & - \\
\hline Adipate & - & - & - \\
\hline Isoamyl alcohol & + & + & - \\
\hline 2,3-Butandiol & + & + & - \\
\hline 1,2-Propandiol & + & + & - \\
\hline Paraffin & + & + & - \\
\hline \multicolumn{4}{|c|}{$\begin{array}{l}\text { Utilization of the following } \\
\text { compounds as sole } \\
\text { sources of carbon and } \\
\text { nitrogen: }\end{array}$} \\
\hline Acetamide & + & + & - \\
\hline Alanine & + & + & - \\
\hline Gelatin & - & - & - \\
\hline Proline & + & + & - \\
\hline Serine & + & + & - \\
\hline \multicolumn{4}{|l|}{ Growth at: } \\
\hline $24^{\circ} \mathrm{C}$ & + & + & + \\
\hline $31^{\circ} \mathrm{C}$ & + & + & + \\
\hline $37^{\circ} \mathrm{C}$ & + & + & + \\
\hline $45^{\circ} \mathrm{C}$ & + & + & - \\
\hline $\begin{array}{l}\text { Growth on MacConkey } \\
\text { agar without crystal } \\
\text { violet }\end{array}$ & + & + & - \\
\hline
\end{tabular}

TABLE 1 -Continued

\begin{tabular}{lccc}
\hline \multicolumn{1}{c}{ Characteristic } & $\begin{array}{c}\text { Strain } \\
\text { IMMIB } \\
\text { D-771 }\end{array}$ & $\begin{array}{c}\text { Strain } \\
\text { IMMIB } \\
\text { AL-1155 }\end{array}$ & $\begin{array}{c}\text { T. paurometabola } \\
\text { DSM 20162 }\end{array}$ \\
\hline Niacin production & - & - & - \\
Enzyme activities & & & + \\
$\quad$ Acetamidase & + & + & + \\
Allantoinase & + & + & - \\
Arylsulfatase (3 days) & - & - & ND \\
Benzamidase & + & - & + \\
Catalase (68 ${ }^{\circ}$ C) & + & + & + \\
B-Glucosidase & + & + & + \\
$\beta$-Galactosidase & + & + & ND \\
Nicotinamidase & + & + & + \\
Nitrate reductase & - & - & + \\
Pyrazinamidase & + & + & + \\
Succinamidase & - & - & + \\
Urease & + & + & + \\
Phosphatase & + & + & + \\
Growth in the presence of: & & & + \\
Streptomycin & + & + & + \\
Isoniazid & + & + & + \\
Ethambutol & + & + & + \\
Rifampin & + & + & + \\
$p$-Aminosalicylic acid & + & + & + \\
Protionamide & + & + & + \\
Capreomycin & + & + & + \\
Cycloserine & + & + & + \\
\hline
\end{tabular}

${ }^{a}-$, negative; + , positive; ND, not determined.

calcium pantothenate, $10.0 \mathrm{mg}$ of $p$-aminobenzoic acid, and $20.0 \mathrm{mg}$ of thiamine hydrochloride). A 4-ml portion of the trace salt solution was added to 1 liter of basal medium, and the preparation was sterilized by autoclaving. After autoclaving, the $\mathrm{pH}$ of the medium was adjusted to $\mathrm{pH} 7.2$ with a sterile $0.1 \mathrm{~N} \mathrm{NaOH}$ solution. To this solution a filter-sterilized solution containing a carbon source (final concentration, $0.02 \mathrm{M}$ ) and $0.2 \mathrm{ml}$ of filter-sterilized vitamin solution per $100 \mathrm{ml}$ were added aseptically. The media were distributed in 2 -ml portions into sterile tubes, and each tube was inoculated with 1 drop of a very thin suspension of bacteria.

A modification of the medium described above was used to determine utilization of various substances as sources of both carbon and nitrogen; this medium contained (per liter of distilled water) $1.5 \mathrm{~g}$ of $\mathrm{KH}_{2} \mathrm{PO}_{4}, 0.5 \mathrm{~g}$ of $\mathrm{MgSO}_{4}$, and 0.1 $\mathrm{g}$ of $\mathrm{CaCl}_{2}$.

Cell chemistry. The strains which we studied were cultivated in shake flasks containing brain heart infusion (Difco) broth for 1 week. After we checked for purity when maximum growth had occurred, the organisms were killed with formaldehyde $(1 \%$, vol/vol), harvested by centrifugation, washed with distilled water, and freeze-dried. Whole-cell hydrolysates were analyzed to determine their amino acid and sugar contents by the methods of Becker et al. (1) and Lechevalier (22). Acid methanolysis, alkaline methanolysis, conversion to tertbutyldimethylsilyl ethers, one-dimensional and two-dimensional thin-layer chromatography, and pyrolysis gas chromatography were performed as previously
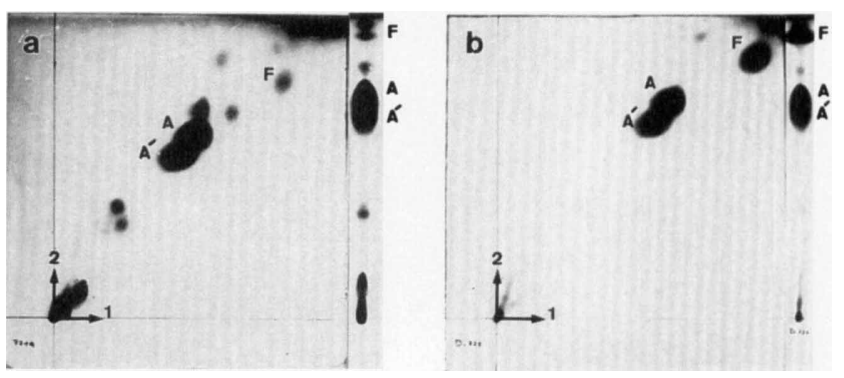

FIG. 1. One-dimensional and two-dimensional thin-layer chromatography of whole-cell alkaline (a) and acid (b) methanolysates of strain IMMIB D-771 T Triple development in the first direction was with petroleum ether (bp 60 to $\left.80^{\circ} \mathrm{C}\right)$-acetone $(95: 5, \mathrm{vol} / \mathrm{vol})$; single development in the second direction was with toluene-acetone (97:3, vol/vol). Spot A, $\alpha$-mycolate; spot $\mathrm{A}^{\prime}, \alpha^{\prime}$-mycolate; spot $F$, nonhydroxylated fatty acid methyl esters. 


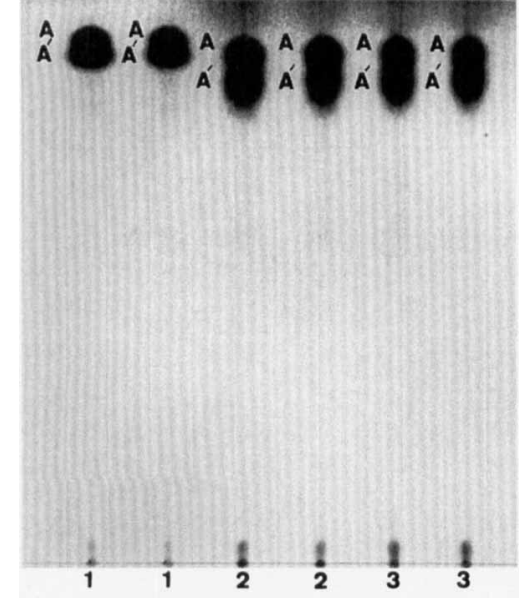

FIG. 2. Thin-layer chromatography of tert-butyldimethylsilyl ethers of alkaline methanolysates of $M$. chelonae (lanes 1), strain IMMIB D-771 $1^{\mathrm{T}}$ (lanes 2), and strain IMMIB AL-1155 (lanes 3). Single development in petroleum ether (bp 60 to $80^{\circ} \mathrm{C}$ )-toluene (70:30, vol/vol) was used. Spot A, $\alpha$-mycolate; spot $\mathrm{A}^{\prime}$, $\alpha^{\prime}$-mycolate (tert-butyldimethylsilyl ethers of the different types of mycolic acid methyl esters).

described by Yassin et al. (38). Menaquinones were extracted and purified by the method of Collins et al. (6) and were identified by using a Finnigan model Mat 212 mass spectrometer.

DNA isolation and characterization. DNA was isolated by chromatography on hydroxyapatite by the method of Cashion et al. (3). $\mathrm{G}+\mathrm{C}$ contents were determined by high-performance liquid chromatography (24). DNA-DNA hybridization experiments were carried out as described previously (39).

$16 S$ rDNA isolation and sequence determination. Genomic DNA extraction and PCR-mediated amplification of $16 \mathrm{~S}$ ribosomal DNA (rDNA) genes were performed as described previously (26). Purified PCR products were directly sequenced by using a Taq DyeDeoxy Terminator Cycle sequencing kit (Applied Biosystems, Foster City, Calif.) according to the protocol provided by the manufacturer. An Applied Biosystems model 373A DNA sequencer was used for electrophoresis of the sequencing reaction mixtures.

The 16S rDNA sequences determined in this study were manually aligned with previously published sequences available from public databases. Evolutionary distances calculated by the method of Jukes and Cantor (17) were used to construct a phylogenetic tree by the least-squares method of De Soete (9).

Nucleotide sequence accession numbers. The $16 \mathrm{~S}$ rDNA sequence of strain
IMMIB D-771 ${ }^{\mathrm{T}}$ is available from EMBL under accession number X85955. The 16S rDNA sequence of strain IMMIB AL-1155 has not been deposited because it is similar to that of strain IMMIB D-771 ${ }^{\mathrm{T}}$

\section{RESULTS AND DISCUSSION}

Cells of strains IMMIB D-771 ${ }^{\mathrm{T}}$ and IMMIB AL-1155 grown on Loewenstein-Jensen medium and on Middlebrook $7 \mathrm{H} 10$ agar were rod shaped, gram positive, and acid-alcohol fast. Spores, capsules, true branching, and aerial hyphae were not observed. At 24 to $45^{\circ} \mathrm{C}$ growth occurred within 1 to 2 days on Loewenstein-Jensen medium, Middlebrook 7H10 agar, and brain heart infusion agar. Dilute inocula on LoewensteinJensen medium, Middlebrook 7H10 agar, and brain heart infusion agar yielded large, eugonic, brownish orange, rough colonies. The physiological properties of strains IMMIB D-771 ${ }^{\mathrm{T}}$ and IMMIB AL-1155 are shown in Table 1. These strains exhibited acetamidase, allantoinase, catalase, $\beta$-glucosidase, $\beta$-galactosidase, nicotinamidase, pyrazinamidase, urease, and phosphatase activities; arylsulfatase, benzamidase, nitrate reductase, and succinamidase activities were not observed. Strains IMMIB D-771 ${ }^{\mathrm{T}}$ and IMMIB AL-1155 did not produce niacin but tolerated $5 \% \mathrm{NaCl}$ and $p$-nitrobenzoic acid. The resistance of both strains to all of the antituberculous drugs tested was characteristic (Table 1). Table 1 shows that the two strains are very similar. The only difference is that strain IMMIB D-771 ${ }^{\mathrm{T}}$ is able to utilize cellobiose as a sole carbon source while strain IMMIB AL-1155 does not assimilate this sugar.

Lipid analysis. One-dimensional thin-layer chromatography of whole-cell acid and alkaline methanolysates of strains IMMIB D-771 ${ }^{\mathrm{T}}$ and IMMIB AL-1155 resulted in identical patterns consisting of long-chain components (Fig. 1). Two-dimensional thin-layer chromatography resulted in more precise resolution of the components into two mycolate spots (spots $\mathrm{A}$ and $\mathrm{A}^{\prime}$ ) in addition to the nonhydroxylated fatty acid spot (spot F) (Fig. 1). One-dimensional thin-layer chromatography of the tert-butyldimethylsilyl ethers of the alkaline methanolysates allowed us to identify mycolate spots $\mathrm{A}$ and $\mathrm{A}^{\prime}$ as $\alpha$ - and $\alpha^{\prime}$ mycolates, respectively, by their $R_{f}$ values (Fig. 2). This myco-

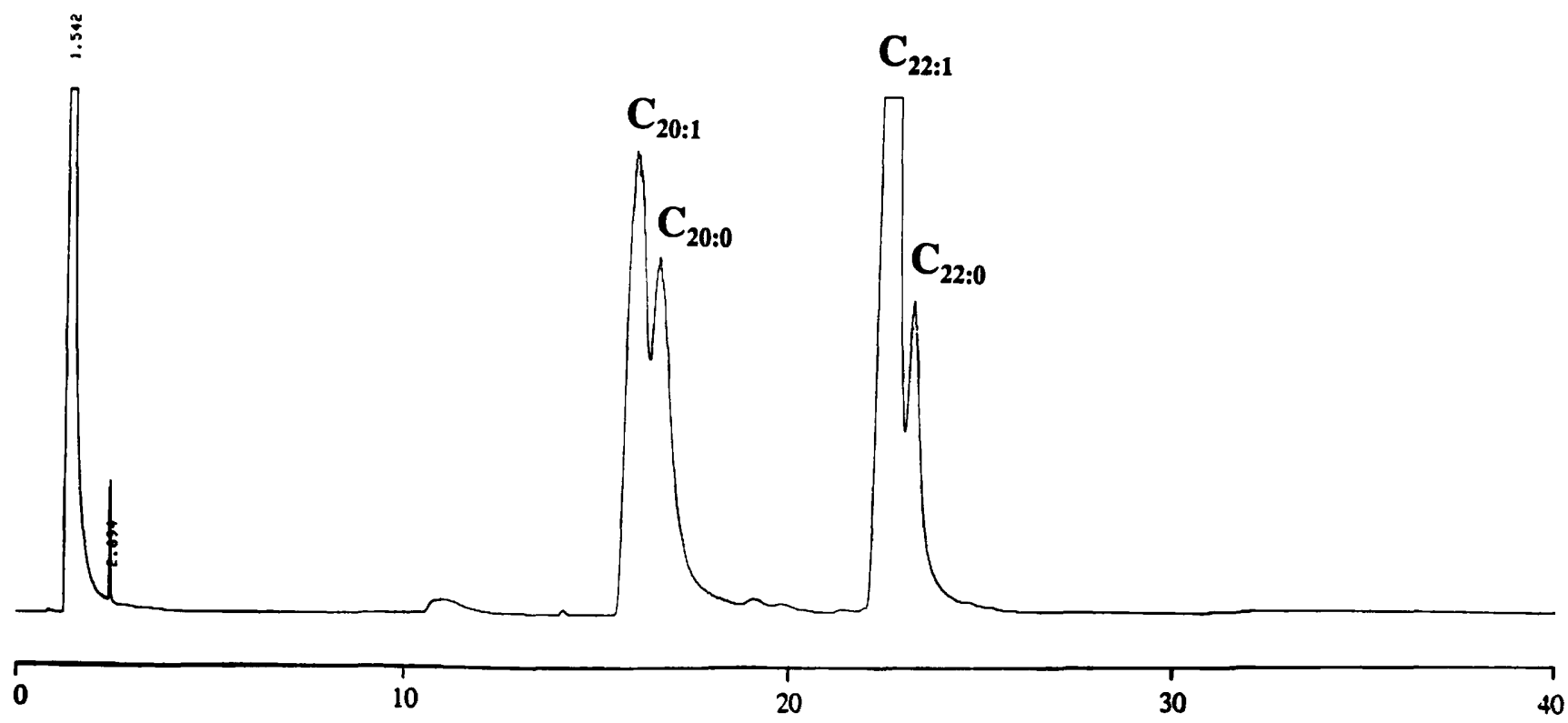

FIG. 3. Pyrolysis gas chromatography of the pure methyl $\alpha$-mycolates from isolate IMMIB D-771 ${ }^{\mathrm{T}}$. 
TABLE 2. Levels of $16 \mathrm{~S}$ rDNA similarity for $T$. inchonensis and related taxa

\begin{tabular}{|c|c|c|c|c|c|c|c|c|c|c|c|c|c|c|c|c|c|c|c|c|}
\hline \multirow[b]{2}{*}{ Species } & \multicolumn{20}{|c|}{$\%$ Similarity to: } \\
\hline & 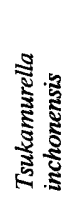 & 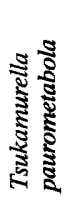 & 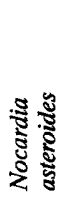 & 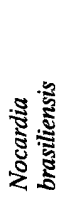 & 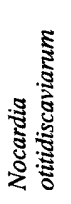 & 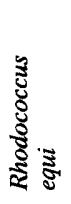 & 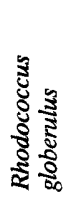 & 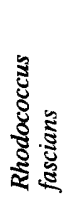 & 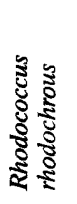 & 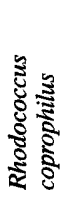 & 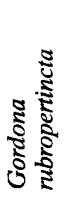 & 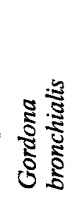 & : & 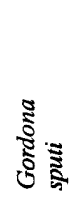 & 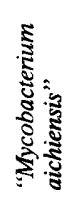 & 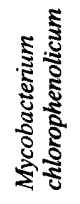 & 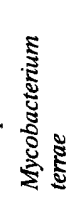 & 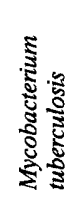 & 芯㺼 & 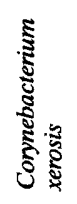 \\
\hline Tsukamurella paurometabola & 99.3 & & & & & & & & & & & & & & & & & & & \\
\hline Nocardia asteroides & 94.6 & 94.7 & & & & & & & & & & & & & & & & & & \\
\hline Nocardia brasiliensis & 93.9 & 93.8 & 97.7 & & & & & & & & & & & & & & & & & \\
\hline Nocardia otitidiscaviarum & 94.7 & 94.6 & 98.0 & 98.4 & & & & & & & & & & & & & & & & \\
\hline Rhodococcus equi & 94.7 & 94.9 & 96.3 & 96.3 & 97.3 & & & & & & & & & & & & & & & \\
\hline Rhodococcus globerulus & 94.7 & 94.8 & 95.2 & 95.0 & 95.9 & 96.5 & & & & & & & & & & & & & & \\
\hline Rhodococcus fascians & 93.9 & 94.1 & 95.1 & 94.7 & 95.2 & 95.9 & 96.7 & & & & & & & & & & & & & \\
\hline Rhodococcus rhodochrous & 94.4 & 94.5 & 94.0 & 94.4 & 95.2 & 96.2 & 95.1 & 94.5 & & & & & & & & & & & & \\
\hline Rhodoc & 94.3 & 94.4 & 94.7 & 94.0 & 95.0 & 95.5 & 95.7 & 95.5 & 97.5 & & & & & & & & & & & \\
\hline rubrop & 93.1 & 93.3 & 93.4 & 94.6 & 94.6 & 94.3 & 93.4 & 93.1 & 94.4 & 93.6 & & & & & & & & & & \\
\hline Gordona bronchialis & 93.3 & 93.4 & 93.5 & 94.8 & 94.8 & 94.4 & 93.8 & 93.2 & 94.4 & 93.8 & 98.5 & & & & & & & & & \\
\hline Gordona terrae & 93.2 & 93.4 & 93.4 & 94.4 & 94.1 & 94.6 & 93.4 & 93.4 & 94.5 & 93.7 & 98.4 & 98.4 & & & & & & & & \\
\hline Gordona sputi & 93.2 & 93.4 & 92.7 & 93.8 & 93.6 & 93.2 & 92.7 & 92.1 & 93.9 & 93.1 & 96.9 & 97.4 & 96.8 & & & & & & & \\
\hline cterium aichiensis" & 94.5 & 94.6 & 94.1 & 93.7 & 94.1 & 93.7 & 94.0 & 93.4 & 93.9 & 94.0 & 93.2 & 93.7 & 93.4 & 93.3 & & & & & & \\
\hline $\begin{array}{l}\text { Mycobacterium } \\
\text { chlorophenolicum }\end{array}$ & 94.4 & 94.6 & 94.4 & 93.9 & 94.1 & 93.7 & 93.8 & 93.4 & 94.0 & 93.9 & 93.2 & 93.8 & 93.5 & 93.0 & 98.4 & & & & & \\
\hline Moch torno & 2.2 & 92.3 & 92.7 & 91.9 & 91.9 & 92.3 & 92.1 & 92.0 & 91.9 & 92.3 & 91.8 & 92.7 & 92.4 & 91.2 & 95.5 & 96.4 & & & & \\
\hline Mycobacterium tuberculosis & 94.1 & 94.1 & 93.5 & 92.9 & 93.1 & 93.1 & 93.2 & 93.0 & 93.4 & 93.5 & 92.7 & 93.2 & 93.0 & 92.7 & 97.3 & 97.4 & 96.8 & & & \\
\hline Dietzia maris & 95.1 & 95.3 & 93.3 & 92.8 & 93.4 & 94.2 & 94.9 & 93.8 & 94.6 & 94.3 & 92.8 & 93.1 & 93.1 & 92.8 & 93.7 & 93.7 & 91.9 & 93.1 & & \\
\hline Cony & 92.3 & 92.3 & 90.7 & 90.5 & 91.5 & 91.9 & 91.9 & 91.8 & 92.4 & 92.6 & 91.4 & 92.2 & 91.6 & 91.1 & 91.7 & 92.1 & 92.2 & 92.2 & 93.4 & \\
\hline Conynebacterium glutamicum & 90.4 & 90.5 & 89.1 & 89.2 & 89.8 & 90.7 & 90.7 & 91.0 & 91.4 & 91.2 & 89.9 & 90.0 & 89.7 & 89.4 & 89.6 & 90.1 & 89.1 & 89.5 & 91.2 & 93.5 \\
\hline
\end{tabular}

late pattern is characteristic of Mycobacterium chelonae (i.e., group II mycobacteria as described by Yassin et al. [38]). However, the $R_{f}$ values of the mycolates from strains IMMIB D-771 ${ }^{\mathrm{T}}$ and IMMIB AL-1155 were less than the $R_{f}$ values of the mycolates from $M$. chelonae (Fig. 2). These differences in $R_{f}$ values reflected differences in the molecular weights of the mycolates of the two species.

Pyrolysis gas chromatography of the pure $\alpha$-mycolates isolated by preparative thin-layer chromatography from strain IMMIB D-771 ${ }^{\mathrm{T}}$ released fatty acid methyl esters of $\mathrm{C}_{20: 0}, \mathrm{C}_{20: 1}$, $\mathrm{C}_{22: 0}$, and $\mathrm{C}_{22: 1}$ fatty acids as the main pyrolytic cleavage products (Fig. 3), while pyrolysis gas chromatography of strain IMMIB AL-1155 released a $C_{22: 0}$ fatty acid methyl ester.

The fatty acid profiles of strains IMMIB D-771 ${ }^{\mathrm{T}}$ and IMMIB AL-1155 were similar. Gas chromatographic analyses of the nonhydroxylated fatty acid methyl esters obtained from both strains revealed that hexadecanoate, octadecanoate, and tuberculostearic acid (10-methyl octadecanoate) were the major

TABLE 3. Chemotaxonomic characteristics of strains IMMIB D$771^{\mathrm{T}}$ and IMMIB AL-1155 and T. paurometabola DSM $20162^{\mathrm{Ta}}$

\begin{tabular}{lcc}
\hline \multicolumn{1}{c}{ Strain } & \multicolumn{1}{c}{ Menaquinones $^{b}$} & $\begin{array}{c}\text { Mycolic acid pyrolytic } \\
\text { product(s) }\end{array}$ \\
\hline IMMIB D-771 $^{\mathrm{T}}$ & MK-10, MK-9, MK-8 & $\mathrm{C}_{20: 0}, \mathrm{C}_{20: 1}, \mathrm{C}_{22: 0}, \mathrm{C}_{22: 1}$ \\
IMMIB AL-1155 $^{\text {MK-10, MK-9, MK-8 }}$ & $\mathrm{C}_{22: 0}$ \\
DSM 20162 $^{\mathrm{T}}$ & MK-9, MK-8, MK-7 & $\mathrm{C}_{20: 0}, \mathrm{C}_{20: 1}, \mathrm{C}_{22: 0}, \mathrm{C}_{22: 1}$ \\
\hline
\end{tabular}

${ }^{a}$ In addition, strains IMMIB D-771 ${ }^{\mathrm{T}}$, IMMIB AL-1155, and DSM $20162^{\mathrm{T}}$ all have the following characteristics: the wall diamino acid is meso-diaminopimelic acid; the wall sugars are galactose and arabinose; the wall chemotype is chemotype IV of Lechevalier and Lechevalier (23); the mycolic acid composition is $\alpha$, $\alpha^{\prime}$; and the fatty acids are straight-chain, monounsaturated, and tuberculostearic acids.

${ }^{b}$ MK-9 is a menaquinone with nine isoprene units.

${ }^{c}$ Data from reference 7 fatty acid methyl esters. No 2-methyl branched-chain fatty acids were observed.

Strains IMMIB D-771 ${ }^{\mathbf{T}}$ and IMMIB AL-1155 both produced a menaquinone pattern consisting of MK-10, MK-9, and MK-8, with MK-9 as the major component.

DNA characteristics. The $\mathrm{G}+\mathrm{C}$ contents of the DNAs of strains IMMIB D-771 ${ }^{\mathrm{T}}$ and IMMIB AL-1155 were $72 \mathrm{~mol} \%$. The levels of relatedness between strain IMMIB D-771 ${ }^{\mathrm{T}}$ DNA and strain IMMIB AL-1155 and $T$. paurometabola DSM $20162^{\mathrm{T}}$ DNAs were 95 and $45 \%$, respectively. The renaturation rate (binding rate) as determined by the optical method between strains IMMIB D-771 ${ }^{\mathrm{T}}$ and IMMIB AL-1155 was $95 \%$. Both strains exhibited a binding rate of $45 \%$ with $T$. paurometabola DSM $20162^{\mathrm{T}}$.

Almost complete 16S rDNA sequences were determined for strains IMMIB D-771 ${ }^{\mathrm{T}}$ and IMMIB AL-1155. A phylogenetic analysis showed that both of these strains are most closely related to the mycolic acid-containing actinomycetes, specifically the genus Tsukamurella (Fig. 4).

The 16S rDNA sequences of strains IMMIB D-771 ${ }^{\mathrm{T}}$ and IMMIB AL-1155 exhibited a similarity value of $100 \%$. The $16 \mathrm{~S}$ rDNA sequence of each of these isolates exhibited a high level of similarity (99.3\%) to the $16 \mathrm{~S}$ rDNA sequence of $T$. paurometabola DSM $20162^{\mathrm{T}}$ (Table 2).

From the data presented above we deduced that strains IMMIB D-771 ${ }^{\mathrm{T}}$ and IMMIB AL-1155 are chemotaxonomically (with the exception of the mycolic acid pyrolysis products), physiologically (with the exception of cellobiose assimilation), and phylogenetically very closely related. This suggests that these two isolates belong to the same species.

On the basis of the results of the 16S rDNA sequence analysis, as well as the shorter chain length of the mycolic acid pyrolytic cleavage products, these two isolates belong to the genus Tsukamurella. In Tables 1 and 3 we compare the 


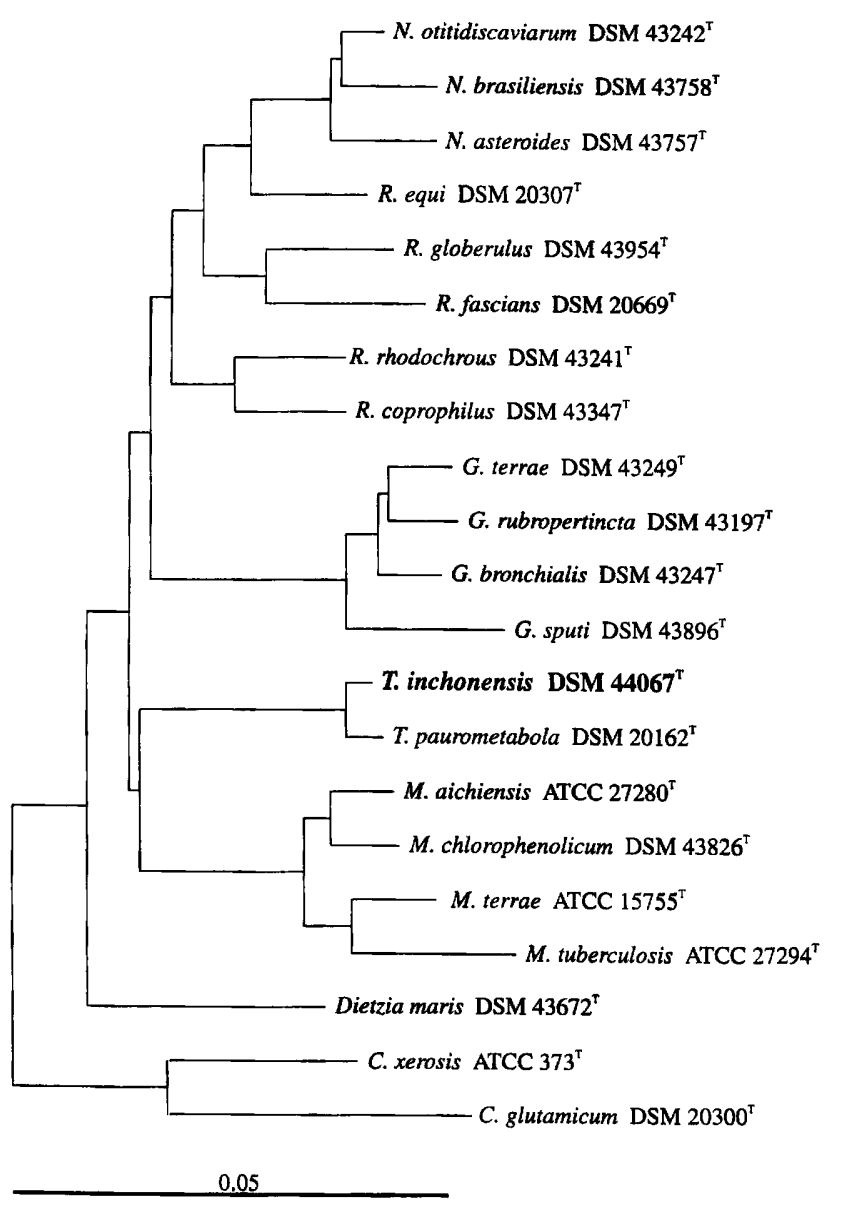

FIG. 4. Phylogenetic dendrogram showing the position of strain IMMIB D-771 ${ }^{\mathrm{T}}$ (= DSM 44067 ${ }^{\mathrm{T}}$ ) within the mycolic acid-containing taxa. Scale bar $=5$ nucleotide substitutions per 100 nucleotides. Abbreviations: N., Nocardia; R., Rhodococcus; G., Gordona; T., Tsukamurella; M., Mycobacterium; C., Corynebacterium.

physiological and chemotaxonomic characteristics of isolates IMMIB D-771 ${ }^{\mathrm{T}}$ and IMMIB AL-1155 with the characteristics of $T$. paurometabola DSM $20162^{\mathrm{T}}$, the type and only previously described species of the genus Tsukamurella. The data in Tables 1 and 3 show that strains IMMIB D-771 ${ }^{\mathrm{T}}$ and IMMIB AL-1155 are very similar to one another, but clearly differ from T. paurometabola DSM $20162^{\mathrm{T}}$. Thus, we propose that strains IMMIB D-771 ${ }^{\mathrm{T}}$ and IMMIB AL-1155 should be placed in a new species of the genus Tsukamurella, Tsukamurella inchonensis, and that strain IMMIB D-771 should be the type strain; strain IMMIB D-771 has been deposited in the Deutsche Sammlung von Mikroorganismen und Zellkulturen $\mathrm{GmbH}$ as strain DSM 44067. The type strain was isolated from a blood culture of a patient who had ingested hydrochloric acid; it was isolated from four different blood cultures taken on different days. Isolate IMMIB AL-1155 originated from lung tissue of a patient suffering from a necrotic tumor of his lung. Therefore, we suggest that $T$. inchonensis should be placed in risk group 2 . A description of this species is given below.

Description of Tsukamurella inchonensis sp. nov. Tsukamurella inchonensis (in. cho. nen' sis. M. L. adj. inchonensis, referring to Inchon, the city in South Korea where the type strain was isolated). Cells are acid-alcohol-fast bacilli. They do not form spores, capsules, or aerial hyphae. Visible growth from dilute inocula occurs within 2 days; colonies on Loewen-
stein-Jensen medium are eugonic, brownish orange, and rough. Growth occurs at $24,31,37$, and $45^{\circ} \mathrm{C}$. The organism has meso-diaminopimelic acid as a wall diamino acid in addition to galactose and arabinose as determined with whole-cell hydrolysates; i.e., the cell wall chemotype is chemotype IV. It has a type $\alpha, \alpha^{\prime}$ mycolate pattern; MK-9 is the major menaquinone, and minor amounts of MK-10 and MK- 8 are also present. This organism produces acetamidase, allantoinase, thermostable catalase, $\beta$-glucosidase, $\beta$-galactosidase, nicotinamidase, pyrazinamidase, urease, and phosphatase but not arylsulfatase, benzamidase, nitrate reductase, and succinamidase. It grows on MacConkey agar without crystal violet and tolerates $5 \% \mathrm{NaCl}$ and $p$-nitrobenzoic acid. Niacin is not produced. Glucose, galactose, maltose, trehalose, sucrose, cellobiose (only one strain), melezitose, inositol, mannitol, sorbitol, acetate, citrate, gluconate, lactate, isoamyl alcohol, 2,3-butandiol, 1,2-propandiol, and paraffin are utilized as sole carbon sources, but arabinose, xylose, rhamnose, lactose, raffinose, adonitol, erythritol, benzoate, $m$-hydroxybenzoate, $p$-hydroxybenzoate, and adipate are not utilized. Acetamide, alanine, proline, and serine are utilized as both nitrogen and carbon sources. Hypoxanthine, urea, esculin, and Tween 80 are hydrolyzed, but adenine, tyrosine, xanthine, casein, gelatin, elastin, guanine, keratin, and testosterone are not hydrolyzed. Acid is produced from glucose, galactose, maltose, trehalose, sucrose, cellobiose (one strain delayed), melezitose, inositol, mannitol, sorbitol, mannose, and fructose, but not from arabinose, $x y-$ lose, rhamnose, lactose, raffinose, adonitol, and inulin. The strains which we tested are resistant to streptomycin, isoniazid, ethambutol, rifampin, $p$-aminosalicylic acid, protionamide, capreomycin, and cycloserine. The $\mathrm{G}+\mathrm{C}$ content of the DNA is $72 \mathrm{~mol} \%$. The type strain of $T$. inchonensis is strain DSM 44067 .

\section{REFERENCES}

1. Becker, B., M. P. Lechevalier, R. E. Gordon, and H. A. Lechevalier. 1964 Rapid differentiation between Nocardia and Streptomyces by paper chromatography of whole cell hydrolysates. Appl. Microbiol. 12:421-423.

2. Bönicke, R. 1962 . Identification of mycobacteria by biochemical methods. Bull. Int. Union Tuberc. 32:13-86.

3. Cashion, P., M. A. Holder-Franklin, J. McCully, and M. Franklin. 1977. A rapid method for the base ratio determination of bacterial DNA. Anal. Biochem. 81:461-466.

4. Collins, M. D., and C. S. Cummins. 1986. Genus Corynebacterium, p. $1266-$ 1276. In P. H. A. Sneath, N. S. Mair, M. E. Sharpe, and J. G. Holt (ed.) Bergey's manual of systematic bacteriology, vol. 2. The Williams \& Wilkins Co., Baltimore.

5. Collins, M. D., and D. Jones. 1982. Lipid composition of Corynebacterium paurometabolum (Steinhaus). FEMS Microbiol. Lett. 13:13-16.

6. Collins, M. D., T. Pirouz, M. Goodfellow, and D. E. Minnikin. 1977. Distribution of menaquinones in actinomycetes and corynebacteria. J. Gen. Microbiol, 100:221-230.

7. Collins, M. D., J. Smida, M. Dorsch, and E. Stackebrandt. 1988. Tsukamurella gen. nov. harboring Corynebacterium paurometabolum and Rhodococcus aurantiacus. Int. J. Syst. Bacteriol. 38:385-391.

8. Cummins, C. S. 1961. Cell wall composition in Corynebacterium bovis and some other corynebacteria. J. Bacteriol. 105:1227-1228.

9. De Soete, G. 1983. A least squares algorithm for fitting additive trees to proximity data. Psychometrika 48:621-626.

10. Goodfellow, M. 1986. Genus Rhodococcus, p. 1472-1481. In P. H. A. Sneath, N. S. Mair, M. E. Sharpe, and J. G. Holt (ed.), Bergey's manual of systematic bacteriology, vol. 2. The Williams \& Wilkins Co., Baltimore.

11. Goodfellow, M. and G. Alderson. 1977. The actinomycete genus Rhodococcus: a home for the "rhodochrous" complex. J. Gen. Microbiol. 100:99-122.

12. Goodfellow, M., P. A. B. Orlean, M. D. Collins, L. Alshamaony, and D. E. Minnikin. 1978. Chemical and numerical taxonomy of strains received as Gordona aurantiaca. J. Gen. Microbiol. 109:57-68.

13. Gordon, R. E. 1966. Some criteria for the recognition of Nocardia madurae (Vincent) Blanchard. J. Gen. Microbiol. 45:355-364.

14. Gordon, R. E., and J. M. Mihm. 1957. A comparative study of some strains received as nocardiae. J. Bacteriol. 73:15-27.

15. Gordon, R. E., and M. M. Smith. 1955. Proposed group of characters for the separation of Streptomyces and Nocardia. J. Bacteriol. 69:147-150.

16. Jones, D. 1975. A numerical taxonomic study of coryneform and related 
bacteria. J. Gen. Microbiol. 87:52-96.

17. Jukes, T. H., and C. R. Cantor. 1969. Evolution of protein molecules, p. 21-132. In H. N. Munro (ed.), Mammalian protein metabolism. Academic Press, New York.

18. Kilburn, J. O., and G. P. Kubica. 1968. Reagent impregnated paper strips for detection of niacin. Am. J. Clin. Pathol. 50:530-532.

19. Kubica, G. P., and H. L. David. 1980. The mycobacteria, p. 1693-1730. In A. C. Sonnenwirth and L. Jarett (ed.), Gradwohl's clinical laboratory methods and diagnosis. The C. V. Mosby Co., St. Louis.

20. Kubica, G. P., and G. L. Pool. 1960. Studies on the catalase activity of acid fast bacilli. I. An attempt to subgroup these organisms on the basis of their catalase activities at different temperatures and pH. Am. Rev. Respir. Dis. 81:387-391.

21. Kubica, G. P., and A. L. Ridgon. 1961. The arylsulfatase activity of acid-fast bacilli. III. Preliminary investigation of rapidly growing acid-fast bacilli. Am. Rev. Respir. Dis. 83:737-740.

22. Lechevalier, M. P. 1968. Identification of aerobic actinomycetes of clinical importance. J. Lab. Clin. Med. 71:934-944.

23. Lechevalier, M. P., and H. A. Lechevalier. 1970. Chemical composition as a criterion in the classification of aerobic actinomycetes. Int. J. Syst. Bacteriol. 20:435-443.

24. Mesbah, M., U. Premachandran, and W. B. Whitman. 1989. Precise measurement of the $\mathrm{G}+\mathrm{C}$ content of deoxyribonucleic acid by high-performance liquid chromatography. Int. J. Syst. Bacteriol. 39:159-167

25. Pattyn, S. R., and F. Portaels. 1972. Identification and clinical significance of mycobacteria. Zentralbl. Bakteriol. Parasitenkd. Infektionskr. Hyg. Abt. 1 Orig. Reihe A 219:114-140.

26. Rainey, F. A. M. Dorsch, H. W. Morgan, and E. Stackebrandt. 1992. 16S rDNA analysis of Spirochaeta thermophila: position and amplifications for the systematics of the order Spirochaetales. Syst. Appl. Microbiol. 16:224 226.

27. Schleifer, K. H., and O. Kandler. 1972. Peptidoglycan types of bacterial cell walls and their taxonomic implications. Bacteriol. Rev. 36:407-477.

28. Steinhaus, E. A. 1941 . A study of the bacteria associated with thirty species of insects. J. Bacteriol. 24:757-790.

29. Tomoysau, I., and I. Yano. 1984. Separation and analysis of novel polyunsaturated mycolic acids from a psychrophilic, acid-fast bacterium, Gordona aurantiaca. Eur. J. Biochem. 139:173-180.
30. Tsukamura, M. 1974. A further taxonomic study of the rhodochrous group. Jpn. J. Microbiol. 18:169-181.

31. Tsukamura, M. 1974. Differentiation of the 'Mycobacterium' rhodochrousgroup from nocardiae by $\beta$-galactosidase activity. J. Gen Microbiol. 80:553 555.

32. Tsukamura, M. 1978. Numerical classification of Rhodococcus (formerly Gordona) organisms recently isolated from sputa of patients. Int. J. Syst. Bacteriol, 28:169-181.

33. Tsukamura, M., and S. Mizuno. 1971. A new species, Gordona aurantiaca, occurring in sputa of patients with pulmonary disease. Kekkaku 46:93-98.

34. Tsukamura, M., and S. Tsukamura. 1965. Differentiation of Mycobacterium tuberculosis and Mycobacterium bovis by $p$-nitrobenzoic acid susceptibility. Tubercle 45:64-65.

35. Tsukamura, M., and I. Yano. 1985. Rhodococcus sputi sp. nov., nom. rev. and Rhodococcus aurantiacus sp. nov., nom. rev. Int. J. Syst. Bacteriol. 35:364-368.

36. Wayne, L. G., H. C. Engbaek, H. W. B. Engel, S. Froman, W. Gross, J. Hawkins, W. Käppler, A. G. Karlson, H. H. Kleeberg, I. Krasnow, G. P. Kubica, C. McDurmont, E. E. Nel, S. R. Pattyn, K. H. Schröder, S. Showalter, I. Tarnock, M. Tsukamura, B. Vergman, and E. Wolinsky. 1974. Highly reproducible techniques for use in systematic bacteriology in the genus Mycobacterium: tests for pigment, urease, resistance to sodium chloride, hydrolysis of Tween 80 , and $\beta$-galactosidase. Int J. Syst. Bacteriol. 24:412419.

37. Wayne, L. G., H. W. B. Engel, C. Grassi, W. Gross, J. Hawkins, P. A. Jenkins, W. Käppler, H. H. Kleeberg, I. Krasnow, E. E. Nel, S. R. Pattyn, P. A Richards, S. Showalter, M. Slosarek, I. Szabo, I. Tarnok, M. Tsukamura, B. Vergmann, and E. Wolinsky. 1976. Highly reproducible techniques for use in systematic bacteriology in the genus Mycobacterium: tests for niacin and catalase and for resistance to isoniazid, thiophene, 2-carboxylic acid hydrazide, hydroxylamine, and p-nitrobenzoate. Int. J. Syst. Bacteriol. 26:311-318.

38. Yassin, A. F, C. Binder, and K. P. Schaal, 1993. Identification of mycobacterial isolates by thin-layer and capillary gas-liquid chromatography under diagnostic routine conditions. Zentralbl. Bakteriol. Int. J. Med. Microbiol. Virol. Parasitol. Infect. Dis. 278:34-48.

39. Yassin, A. F., E. A. Galinski, A. Wohlfarth, K.-D. Jahnke, K. P. Schaal, and H. G. Trüper. 1993. A new actinomycete species, Nocardiopsis lucentensis sp. nov. Int. J. Syst. Bacteriol. 43:266-271. 